\title{
Cephalometric Norms for Orthognathic Surgery in Local Andhra Pradesh Population
}

\section{Manish Pisarla ${ }^{1}$, Tejaswi Kala ${ }^{2 *}$, Rajivi Kalpakuri ${ }^{3}$, Ravalika N Kothuri $^{4}$, Jadhav Sachin Kumar ${ }^{5}$ and Srikanth Kadavergu ${ }^{6}$}

${ }^{1}$ Assistant Professor, Department of Orthodontics and Dentofacial Orthopaedics, Meghana Institute of Dental Sciences, Nizamabad, Telangana, India

${ }^{2}$ Assistant Professor, Department of Public Health Dentistry, Tirumala Institute of

Dental Sciences, Nizamabad, Telangana, India

${ }^{3}$ Assistant Professor, Department of Orthodontics and Dentofacial Orthopaedics,

Vydehi Institute of Dental Sciences, Bangalore, Karnataka, India

${ }^{4}$ Researcher and Private Practitioner, Clean and Correct Dentistry, Hyderabad,

Telangana, India

${ }^{5}$ Post Graduate Student, Department of Public Health Dentistry, Post Graduate

Institute of Dental Sciences, Rohtak, Haryana, India

${ }^{6}$ Senior Resident, Department of Dental Surgery, Govt Medical College, Siddipet,

India

*Corresponding Author: Tejaswi Kala, Assistant Professor, Department of Public

Health Dentistry, Tirumala Institute of Dental Sciences, Nizamabad, Telangana, India.
Received: July 28, 2021

Published: August 21, 2021

(C) All rights are reserved by Tejaswi Kala., et al.

\section{Abstract}

Aim: The aim of the present study was to establish hard and soft tissue cephalometric norms for orthognathic surgery (COGS) in Andhra Pradesh population.

Materials and Methods: The digital lateral cephalogram of 100 subjects was taken of which 50 were male and 50 females in Andhra Pradesh. Population within the age range of 18 - 25 years. The cephalograms were traced, analyzed and Burstone's analysis was used for hard tissue interpretation and Legan and Burstone analysis for soft tissue interpretation respectively. The standard deviation and mean deviation were calculated to compare between the groups.

Results: The anterior cranial base length; the posterior maxillary height; the antero-posterior maxillary length; the ramal length, posterior facial height to anterior facial height ratio, the inclination of maxillary incisor, lower lip prominence and the depth of the mento-labial sulcus was significantly more in the Andhra Pradesh population than the Caucasian group.

Conclusion: The results obtained of the Andhra Pradesh population can be used as cephalometric norms for orthognathic surgery.

Keywords: Lateral Cephalograms; COGS Analysis; Orthognathic Surgery

\section{Introduction}

In the recent times facial aesthetics has gained great attention in dentistry. The triumph of orthodontic treatment is often related to the improvement in fascial appearance of patient which includes both soft and hard tissue profile, since there is a considerable variations in soft tissue covering, the diagnosis and treatment planning will be miss leaded if based only on dental or skeletal measurements alone, hence soft tissue analysis is mandatory [1]. 
Cephalometry is a radiographic technique for determining precise dentofacial measurements, which subsequently assist in making orthodontic diagnoses, planning treatment, and tracking outcomes [2]. The recent refinements in orthognathic surgical procedures and an increasing sophistication in diagnosis and treatment planning have offered to patients with the most complex dentofacial problems, the option of treatment to correct their skeletal jaw deformity and align their teeth. Cephalometrics is a reliable and reproducible diagnostic modality for orthognathic surgical planning. Numerous osseous cephalometric analyses are reported in the literature to diagnose and plan orthognathic surgery [3].

For evaluation of orthognathic surgical patients, a specialized Cephalometric appraisal system, called Cephalometrics for Orthognathic Surgery (COGS) was developed at the University of Connecticut. The COGS system describes dental, skeletal and soft tissue variations. This system describes the horizontal and vertical position of facial bones by use of a constant coordinate system. The sizes of bones are represented by direct linear dimensions, and shapes of the bone by angular measurements. The chosen landmarks and measurements can be altered by copious surgical procedures; the comprehensive appraisal includes all of the facial bones and a cranial base reference; rectilinear measurements can be readily transferred to a study case for mock surgery [4].

\section{Aim of the Study}

To evaluate the cephalometric features of a Andhra Pradesh ethnic population and to establish cephalometric hard and soft tissue norms for orthognathic surgery patients in Andhra Pradesh population.

\section{Objectives of the Study}

1. To compare established norms so derived with the earlier established norms for other populations.

2. To compare the cephalometric norms between male and female subjects of Andhra Pradesh ethnic population.

\section{Materials and Methods}

Present cross-sectional study was conducted in the Department of Orthodontics and Dentofacial Orthopaedics, Kamineni Institute of Dental Sciences and Hospitals, Narketpally, Nalgonda, Andhra Pradesh.

The sample consisted of 100 adult subjects (50 males and 50 females) of Indian origin, selected from the subject visiting to Ka- mineni Institute of Dental Sciences Hospital. The age ranged between 18 to 25 years.

\section{Inclusion criteria}

1. Person native of Andhra Pradesh

2. Age group 18 - 25 years.

3. Class I molar relation.

4. Permanent teeth with proper intercuspation.

5. Normal overbite and overjet.

\section{Exclusion criteria}

1. Person with major skeletal and dental abnormalities.

2. History of trauma or surgery in maxillofacial region

3. Periodontal diseases.

4. Presence of or over retained or deciduous teeth.

Using this inclusion and exclusion criteria subjects were selected and standardized lateral cephalometric radiographs were taken. Informed signed consent was obtained from all the participants after explaining the nature and purpose of the radiograph.

The records include extra oral photographs and lateral cephalogram of each patient. The cephalometric radiographic apparatus used was VILLA MEDICAL SYSTEM, a Digital panaromic and cephalometric system.

Lateral cephalograms were taken in Natural head position (Viazis method). The horizontal head position was maintained by the cephalostat itself and the teeth were in centric occlusion. The radiographs were exposed at $72 \mathrm{KV} / 8 \mathrm{~mA}$ for 0.8 second. The film to source distance was $5 \mathrm{ft} 2$ ", and the distance between the film and patient's mid-sagittal plane was 6".

The cephalograms were traced by affixing transparent 120 micron polyester tracing paper to the cephalometric radiographs with a transparent tape with a $0.3 \mathrm{~mm}$ lead pencil. A single operator performed the tracings in a standardized manner to avoid errors due to intra-operator variations.

To determine the errors associated with radiographic measurements, 15 radiographs were selected randomly. Their tracings and measurements were repeated. A paired $t$-test was applied to the first and second measurements. The difference between the first and second measurements of the 20 radiographs was insignificant. 
All the tracings were subjected to COGS (Cephalometrics for Orthognathic Surgery) analysis, both for hard and soft tissues as described by Burstone., et al [6].

The data obtained from the sample was subjected to statistical analysis by SPSS software version 19.0 (Statistical Package for the Social Services),

\section{Results}

A total of 100 subjects were chosen for the study, consisting of 50 men and 50 women of 18-25 years age group. Standardized lateral cephalograms were taken and analyzed.

Comparison of hard tissue parameters between male and females population of Andhra Pradesh

The results of analysis of variance indicated the presence of the following significant differences between Caucasian and Andhra Pradesh females.

Cranial base parameters: Ar-Ptm is significantly greater in Andhra Pradesh males.

Skeletal horizontal parameters: There are no parameters of significance.

Skeletal vertical parameters: N-ANS, ANS-Gn, PNS-N, MP-HP (angle) is significantly greater in Andhra Pradesh males.

Dental parameters: 1-NF, 1-MP, 6-NF, 6-MP, OP-HP (angle) are greater in Caucasian females while 1-NF (angle), 1-MP (angle) are greater in Andhra Pradesh females.

Maxilla-mandible parameters: PNS-ANS, Ar-Go, Go-Pg, B-Pg are greater in Andhra Pradesh males Ar-Go-Gn (angle) is greater in Andhra Pradesh females.

\section{Discussion}

Life style of today's epoch demands the high aesthetics perception. Macro aesthetics, micro aesthetics, mini-aesthetics have been emphasized and orthodontic ethics has been linked to improve the lip, nose and chin balance [5].

The attainment of facial proportion is the principal goal in the treatment of dentofacial abnormality [4]. Soft tissues analysis has made easier for orthodontist and maxillofacial surgeon in diagnosis and treatment planning [6]. As health professionals have in- creased their ability to change faces, the necessity to understand what is and what is not beautiful has intensified. Disproportionate human faces are generally unaesthetic, whereas proportionate features are acceptable if not always beautiful. By knowing the hard and soft tissue traits and their normal range in a population, a treatment plan can be designed to normalize the facial traits for a given individual. There are many factors that affect the soft tissue profile like cultural origin, Ethnicity, age, gender difference [7] because of this reason facial characteristics have been studied in different ethnic groups [1]. Different soft tissue analysis has been introduced by various authors such as Bergman analysis [8], Arnett analysis [6], Holdaway analysis.

In the present study two different comparisons were done to evaluate the facial structures for hard tissue analysis; comparison between Andhra Pradesh males and females and comparison between Andhra Pradesh population and Caucasian population.

Comparison of hard tissue parameters between Andhra Pradesh males and females revealed (Table 1) that Ar-Ptm is significantly greater in Andhra Pradesh males which is in contrast to the study done by kalyani Trivedi., et al [4]. N-ANS, ANS-Gn, PNS-N, MP-HP (angle) is significantly greater in Andhra Pradesh males. 1-NF, 1-MP, 6-NF, 6-MP, OP-HP (angle) are greater in Caucasian females while 1-NF (angle), 1-MP (angle) are greater in Andhra Pradesh females. Females had greater middle and lower third facial height, anterior divergence of mandible, which is similar to the study done by Grewal., et al [9]. Comparison of soft tissue parameters between Andhra Pradesh male and female population (Table 2) showed that G-Sn, G-Pg' are significantly greater in Andhra Pradesh female, results were similar to that of Ankur Mittal., et al [10]. While G-Sn/SnMe', Si to (Li-Pg') is significantly greater in Andhra Pradesh males.

\begin{tabular}{|c|c|c|c|c|c|}
\hline \multirow[b]{2}{*}{ Parameter } & \multicolumn{2}{|c|}{ Male } & \multicolumn{2}{|c|}{ Female } & \multirow{2}{*}{$\begin{array}{c}P \text { - } \\
\text { value }\end{array}$} \\
\hline & Mean & $\begin{array}{c}\text { Std. } \\
\text { Deviation }\end{array}$ & Mean & $\begin{array}{c}\text { Std. } \\
\text { Deviation }\end{array}$ & \\
\hline $\begin{array}{l}\text { Ar-Ptm } \\
(\mathrm{mm})\end{array}$ & 38.6800 & 3.22262 & 34.4400 & 3.61494 & 0.001 \\
\hline N-Ptm (mm) & 48.8000 & 3.03046 & 48.7200 & 3.56880 & 0.904 \\
\hline N-A-Pg $\left({ }^{0}\right)$ & 1.5000 & 3.52397 & 2.4600 & 3.45354 & 0.172 \\
\hline $\mathrm{NA}(\mathrm{mm})$ & 1.5200 & 3.17027 & .5800 & 2.72621 & 0.115 \\
\hline $\mathrm{NB}(\mathrm{mm})$ & 1.0800 & 4.58409 & 1.0000 & 3.95897 & 0.926 \\
\hline $\mathrm{N}-\mathrm{Pg}(\mathrm{mm})$ & 2.1200 & 5.04122 & 1.1000 & 3.98082 & 0.264 \\
\hline N-ANS (mm) & 49.6200 & 3.37391 & 46.8000 & 2.49898 & 0.001 \\
\hline
\end{tabular}


Cephalometric Norms for Orthognathic Surgery in Local Andhra Pradesh Population

\begin{tabular}{|c|c|c|c|c|c|}
\hline $\begin{array}{l}\text { ANS-Gn } \\
(\mathrm{mm})\end{array}$ & 62.8200 & 4.68471 & 57.6400 & 4.07962 & 0.001 \\
\hline PNS-N (mm) & 53.1200 & 3.28658 & 48.5800 & 2.53216 & 0.001 \\
\hline MP-HP $\left({ }^{\circ}\right)$ & 16.7000 & 3.90316 & 18.6000 & 2.60298 & 0.005 \\
\hline $\begin{array}{l}1-\mathrm{NF}(\mathrm{lin}) \\
(\mathrm{mm})\end{array}$ & 27.8600 & 3.07066 & 25.7800 & 2.77224 & 0.001 \\
\hline $\begin{array}{l}\text { 1-MP(lin) } \\
(\mathrm{mm})\end{array}$ & 37.8200 & 3.00129 & 34.5800 & 1.81928 & 0.001 \\
\hline 6-NF (mm) & 24.3400 & 2.59992 & 21.9000 & 2.29685 & 0.001 \\
\hline 6-MP (mm) & 30.0800 & 2.97500 & 27.2000 & 2.70298 & 0.001 \\
\hline $\begin{array}{l}\text { PNS-ANS } \\
(\mathrm{mm})\end{array}$ & 52.5600 & 3.56949 & 49.7000 & 2.63609 & 0.001 \\
\hline Ar-Go (mm) & 51.7400 & 3.92173 & 46.0000 & 3.59137 & 0.001 \\
\hline Go-Pg (mm) & 79.2600 & 4.21276 & 73.6000 & 3.32584 & 0.001 \\
\hline B-Pg (mm) & 6.9200 & 1.57584 & 5.8400 & 1.37559 & 0.001 \\
\hline Ar-Go-Gn $\left({ }^{0}\right)$ & 120.0400 & 4.96091 & 121.9200 & 3.89054 & 0.038 \\
\hline OP-HP( $\left.{ }^{0}\right)$ & 3.4600 & 3.52374 & 4.6800 & 2.54302 & 0.050 \\
\hline $\mathrm{A}-\mathrm{B}(\mathrm{mm})$ & -0.0800 & 2.13656 & -0.7800 & 2.26139 & 0.115 \\
\hline $1-\mathrm{NF}\left({ }^{0}\right)$ & 118.4600 & 5.18321 & 117.0000 & 5.65685 & 0.182 \\
\hline $1 \mathrm{Mp}\left({ }^{0}\right)$ & 102.0400 & 4.95267 & 100.6200 & 5.99622 & 0.200 \\
\hline
\end{tabular}

\begin{tabular}{|l|c|c|c|c|}
\hline \multirow{2}{*}{ Si to (Li-Pg') } & Males & 6.5800 & 1.35662 & \multirow{2}{*}{.001} \\
\cline { 2 - 4 } & Females & 5.6000 & 1.06904 & \\
\hline \multirow{2}{*}{ Sn-Stm $_{\mathrm{s}} / \mathrm{Stm}_{\mathrm{i}}$-Me' } & Males & .4380 & .05675 & \multirow{2}{*}{.442} \\
\cline { 2 - 4 } & Females & .4300 & .04629 & \\
\hline \multirow{2}{*}{ Stm-1 } & Males & .0400 & .28284 & \multirow{2}{*}{.401} \\
\cline { 2 - 4 } & Females & .1000 & .41650 & \\
\hline \multirow{2}{*}{ Stm $_{\mathrm{s}}-$ Stm $_{\mathrm{i}}$} & Males & .0400 & .28284 & \multirow{2}{*}{.401} \\
\cline { 2 - 4 } & Females & .1000 & .41650 & \\
\hline
\end{tabular}

Table 2: Descriptive statistics and results of soft tissue COGS comparisons between male and female population of Andhra Pradesh. Significant at P-value $<0.05$ level of confidence.

\section{Comparison of soft tissue parameters between Andhra Pradesh male and female population}

The results of analysis of variance indicated the presence of the following significant differences between Andhra Pradesh male and female population.

Facial form parameters: G-Sn, G-Pg' are significantly greater in Andhra Pradesh female. While G-Sn/Sn-Me' is significantly greater in Andhra Pradesh males.

Table 1: Descriptive statistics and results of hard tissue COGS comparisons between male and female population of Andhra Pradesh.

Lip position and form: $\mathrm{Si}$ to ( $\left.\mathrm{Li}-\mathrm{Pg}^{\prime}\right)$ is significantly greater in Andhra Pradesh male.

COGS analysis comparison between Andhra Pradesh popula-

\begin{tabular}{|l|c|c|c|c|}
\hline Parameter & Group & Mean & $\begin{array}{c}\text { Std. } \\
\text { Deviation }\end{array}$ & $\begin{array}{c}\text { Std. Error } \\
\text { Mean }\end{array}$ \\
\hline \multirow{2}{*}{ G-Sn-Pg' $\left({ }^{0}\right)$} & Males & 11.5600 & 2.94272 & \multirow{2}{*}{.173} \\
\cline { 2 - 4 } & Females & 10.8000 & 2.58725 & \\
\hline \multirow{2}{*}{ G-Sn $(\mathrm{mm})$} & Males & 6.9000 & 1.83225 & \multirow{2}{*}{.009} \\
\cline { 2 - 4 } & Females & 5.8800 & 1.96542 & \\
\hline \multirow{2}{*}{ G-Pg' $(\mathrm{mm})$} & Males & 4.7400 & 4.64587 & \multirow{2}{*}{.027} \\
\cline { 2 - 4 } & Females & 3.0200 & 2.81026 & \\
\hline \multirow{2}{*}{ G-Sn/Sn-Me' } & Males & .9788 & .06489 & \multirow{2}{*}{.001} \\
\cline { 2 - 4 } & Females & 1.0238 & .05810 & \\
\hline \multirow{2}{*}{ Cm-Sn-L $\left.{ }_{s}{ }^{0}\right)$} & Males & 101.1200 & 5.39705 & \multirow{2}{*}{.337} \\
\cline { 2 - 4 } & Females & 100.1200 & 4.95959 & \\
\hline \multirow{2}{*}{$\mathrm{L}_{\mathrm{s}}$ to $\left(\mathrm{Sn}-\mathrm{Pg}^{\prime}\right)$} & Males & 4.0000 & 1.69031 & \multirow{2}{*}{.688} \\
\cline { 2 - 4 }$(\mathrm{mm})$ & Females & 3.8800 & 1.25584 & \\
\hline \multirow{2}{*}{$\mathrm{L}_{\mathrm{i}}$ to $\left(\mathrm{Sn}-\mathrm{Pg}^{\prime}\right)$} & Males & 3.7400 & 1.46817 & \multirow{2}{*}{.096} \\
\cline { 2 - 4 } & Females & 3.2600 & 1.38225 & \\
\hline
\end{tabular}
tion with Caucasian population (Table 3 and 4) revealed N-Ptm, NANS, ANS-Gn, PNS-N, MP-HP (angle), PNS-ANS, B-Pg is significantly greater in Caucasian female.

\begin{tabular}{|l|c|c|c|c|c|}
\hline \multirow{2}{*}{ Parameter } & \multicolumn{2}{|c|}{$\begin{array}{c}\text { Caucasians } \\
\text { female }\end{array}$} & \multicolumn{2}{c|}{$\begin{array}{c}\text { Andhra pradesh } \\
\text { female }\end{array}$} & \multirow{2}{*}{ P-value } \\
\cline { 2 - 6 } & Mean & $\begin{array}{c}\text { Std. } \\
\text { Deviation }\end{array}$ & Mean & $\begin{array}{c}\text { Std. } \\
\text { Deviation }\end{array}$ & \\
\hline Ar-Ptm (mm) & 32.8 & 1.9 & 34.4400 & 3.61494 & 0.0953 \\
\hline N-Ptm (mm) & 50.9 & 3.0 & 48.7200 & 3.56880 & 0.0308 \\
\hline N-A-Pg $\left(^{\circ}\right)$ & $2.6^{\circ}$ & $5.1^{\circ}$ & 2.4600 & 3.45354 & 0.9009 \\
\hline NA (mm) & -2.0 & 3.7 & .5800 & 2.72621 & 0.0037 \\
\hline NB (mm) & -6.9 & 4.3 & 1.0000 & 3.95897 & 0.0001 \\
\hline N-Pg (mm) & -6.5 & 5.1 & 1.1000 & 3.98082 & 0.0001 \\
\hline N-ANS (mm) & 50.0 & 2.4 & 46.8000 & 2.49898 & 0.0001 \\
\hline ANS-Gn (mm) & 61.3 & 3.3 & 57.6400 & 4.07962 & 0.0018 \\
\hline PNS-N (mm) & 50.6 & 2.2 & 48.5800 & 2.53216 & 0.0057 \\
\hline
\end{tabular}




\begin{tabular}{|c|c|c|c|c|c|}
\hline MP-HP $\left({ }^{\circ}\right)$ & $24.2^{\circ}$ & $5.0^{\circ}$ & 18.6000 & 2.60298 & 0.0001 \\
\hline $\begin{array}{l}\text { 1-NF(lin) } \\
(\mathrm{mm})\end{array}$ & 27.5 & 1.7 & 25.7800 & 2.77224 & 0.0224 \\
\hline $\begin{array}{l}\text { 1-MP(lin) } \\
(\mathrm{mm})\end{array}$ & 40.8 & 1.8 & 34.5800 & 1.81928 & 0.0001 \\
\hline 6-NF (mm) & 23.0 & 1.3 & 21.9000 & 2.29685 & 0.063 \\
\hline 6-MP (mm) & 32.1 & 1.9 & 27.2000 & 2.70298 & 0.0001 \\
\hline $\begin{array}{l}\text { PNS-ANS } \\
(\mathrm{mm})\end{array}$ & 52.6 & 3.5 & 49.7000 & 2.63609 & 0.0008 \\
\hline Ar-Go (mm) & 46.8 & 2.5 & 46.0000 & 3.59137 & 0.4111 \\
\hline Go-Pg (mm) & 74.3 & 5.8 & 73.6000 & 3.32584 & 0.5485 \\
\hline B-Pg (mm) & 7.2 & 1.9 & 5.8400 & 1.37559 & 0.0026 \\
\hline Ar-Go-Gn $\left({ }^{0}\right)$ & $122.0^{\circ}$ & $6.9^{\circ}$ & 121.9200 & 3.89054 & 0.9536 \\
\hline OP-HP $\left({ }^{0}\right)$ & $7.1^{\circ}$ & $2.5^{\circ}$ & 4.6800 & 2.54302 & 0.0014 \\
\hline A-B (mm) & -0.4 & 2.5 & -.7800 & 2.26139 & 0.5702 \\
\hline $1-\mathrm{NF}\left({ }^{0}\right)$ & $112.5^{\circ}$ & $5.3^{\circ}$ & 117.0000 & 5.65685 & 0.0062 \\
\hline $1 \mathrm{Mp}\left({ }^{0}\right)$ & $95.9^{\circ}$ & $5.7^{\circ}$ & 100.6200 & 5.996220 & 0.0072 \\
\hline
\end{tabular}

\begin{tabular}{|c|c|c|c|c|}
\hline Parameter & Group & Mean & $\begin{array}{c}\text { Std. } \\
\text { Deviation }\end{array}$ & $\begin{array}{c}\text { Std. Error } \\
\text { Mean }\end{array}$ \\
\hline \multirow{2}{*}{ G-Sn-Pg' } & Caucasian & $12.0^{\circ}$ & $4.0^{\circ}$ & \multirow[b]{2}{*}{0.2060} \\
\hline & Andhra Pradesh & 11.18 & 2.782993 & \\
\hline \multirow{2}{*}{ G-Sn } & Caucasian & 6.0 & 3.0 & \multirow[b]{2}{*}{0.4027} \\
\hline & Andhra Pradesh & 6.39 & 1.958638 & \\
\hline \multirow{2}{*}{ G-Pg' } & Caucasian & 0.0 & 4.0 & \multirow[b]{2}{*}{0.0001} \\
\hline & Andhra Pradesh & 3.88 & 3.916502 & \\
\hline \multirow{2}{*}{ G-Sn/Sn-Me' } & Caucasian & 1.0 & 0.0 & \multirow[b]{2}{*}{0.0001} \\
\hline & Andhra Pradesh & 1.0013 & 0.065314 & \\
\hline \multirow{2}{*}{$\mathrm{Cm}-\mathrm{Sn}-\mathrm{L}_{\mathrm{s}}$} & Caucasian & $102.0^{\circ}$ & $8.0^{\circ}$ & \multirow[b]{2}{*}{0.2663} \\
\hline & Andhra Pradesh & 100.62 & 5.181123 & \\
\hline \multirow{2}{*}{$\mathrm{L}_{\mathrm{s}}-\mathrm{Sn}-\mathrm{Pg}$} & Caucasian & 3.0 & 1.0 & \multirow[b]{2}{*}{0.0014} \\
\hline & Andhra Pradesh & 3.94 & 1.482695 & \\
\hline \multirow{2}{*}{$\mathrm{L}_{\mathrm{i}}-\mathrm{Sn}-\mathrm{Pg}$} & Caucasian & 2.0 & 1.0 & \multirow[b]{2}{*}{0.0001} \\
\hline & Andhra Pradesh & 3.5 & 1.438995 & \\
\hline \multirow{2}{*}{ Si(Li-Pg') } & Caucasian & 4.0 & 2.0 & \multirow[b]{2}{*}{0.0001} \\
\hline & Andhra Pradesh & 6.09 & 1.311141 & \\
\hline \multirow{2}{*}{$\begin{array}{l}\text { Sn-Stm } / \\
\text { Stm } \\
\text { i }-M^{\prime}\end{array}$} & Caucasian & 0.5 & 0.0 & \multirow[b]{2}{*}{0.0001} \\
\hline & Andhra Pradesh & 0.434 & 0.051679 & \\
\hline \multirow{2}{*}{ Stm-1 } & Caucasian & 2.0 & 2.0 & \multirow[b]{2}{*}{0.0001} \\
\hline & Andhra Pradesh & 0.07 & 0.355477 & \\
\hline \multirow{2}{*}{$\mathrm{Stm}_{\mathrm{s}}-\mathrm{Stm}_{\mathrm{i}}$} & Caucasian & 2.0 & 2.0 & \multirow[b]{2}{*}{0.0001} \\
\hline & Andhra Pradesh & 0.07 & 0.355477 & \\
\hline
\end{tabular}

Table 3: Descriptive statistics and results of hard tissue COGS comparisons between Caucasian and Andhra Pradesh females.

Significant at P-value $\leq 0.05$ level of confidence.

\section{Comparison of hard tissue parameters between Caucasian and Andhra Pradesh females}

The results of analysis of variance indicated the presence of the following significant differences between Caucasian and Andhra Pradesh females

Cranial base parameters: N-Ptm is significantly greater in Caucasian female.

Skeletal horizontal parameters: N-A, N-B, N-Pg is significantly greater in Andhra Pradesh females.

Skeletal vertical parameters: N-ANS, ANS-Gn, PNS-N, MP-HP (angle) is significantly greater in Caucasian females.

Dental parameters: 1-NF, 1-MP, 6-MP, OP-HP (angle) are greater in Caucasian females while 1-NF (angle), 1-MP (angle) are greater in Andhra Pradesh females.

Maxilla-Mandible parameters: PNS-ANS, B-Pg are greater in Caucasian females.

Table 4: Descriptive statistics and results of soft tissue COGS comparisons between Caucasian and Andhra Pradesh population. Significant at $\mathrm{P}$-value $\leq 0.05$ level of confidence.

N-A, N-B, N-Pg 1-NF, 1-MP, 6-MP, OP-HP (angle) are greater in Caucasian females while 1-NF (angle), 1-MP (angle) are greater in Andhra Pradesh females.

\section{Conclusion}

The results of this study pointed to the following conclusions: 
1. The anterior cranial base length; the posterior maxillary height; the antero-posterior maxillary length; the ramal length, posterior facial height to anterior facial height ratio, the inclination of maxillary incisor was significantly more in the Andhra Pradesh group than the Caucasian group.

2. The chin prominence and the vertical eruption of lower incisor was significantly less in the Andhra Pradesh group than the Caucasian group.

3. The middle third to lower third height ratio, the lower vertical height to depth ratio, the upper lip length to lower lip length ratio and the inter-labial gap were significantly less in the Andhra Pradesh group than the Caucasian group.

4. The lower lip prominence and the depth of the mento-labial sulcus were significantly more in the Andhra Pradesh group than the Caucasian group.

\section{Bibliography}

1. Khot PJ., et al. "Evaluation of Soft Tissue Cephalometric Norms for Maharashtrian Population Using Holdaway Analysis". International Journal of Scientific Study 5.11 (2018): 29-33.

2. Randall F. "Developing a Standardized Cephalometric Vocabulary: Choices and Possible Strategies". Journal of Dental Education 72.9 (2008): 989-997.

3. Abhilasha 0 Yadav., et al. "Datarkar Cephalometric norms for Central Indian population. using Burstone and Legan analysis". Indian Journal of Dental Research 22.1 (2011): 28-33.

4. Kalyani Trivedi., et al. "Analysis of cephalometrics for orthognathic surgery: Determination of norms applicable to Rajasthani population". National Journal of Maxillofacial Surgery 1.2 (2010): 102-107.

5. Asad S., et al. "Assessment of antero-posterior position of lips: E-Line- S-Line". Pakistan Oral and Dental Journal 31 (2011): 8487.

6. Arnett GW., et al. "Soft tissue cephalometric analysis: Diagnosis and treatment planning of dentofacial deformity". American Journal of Orthodontics and Dentofacial Orthopedics 116 (1999): 239-253.

7. Aghili H., et al. "Soft tissue cephalometric norms in Iranian normal subjects". International Journal of Medical Research and Health Sciences 5 (2016): 149-155.
8. Bergman RT. "Cephalometric soft tissue facial analysis". American Journal of Orthodontics and Dentofacial Orthopedics 116 (1999): 373-389.

9. Grewal H., et al. "Cephalometric appraisal of the craniofacial pattern in Indo-Aryans". Journal of Indian Orthodontic Society 26 (1995): 43-48.

10. Mittal A., et al. "Are We Similar to Caucasians"-Orthognathic Surgery for North Indians". International Journal of Orthodontics 2.4 (2014): 80-86.

\section{Volume 5 Issue 9 September 2021}

(C) All rights are reserved by Tejaswi Kala., et al. 